\title{
Characterization of two bacteriocins produced by Pediococcus acidilactici isolated from "Alheira", a fermented sausage traditionally produced in Portugal
}

\author{
Helena Albano ${ }^{\mathrm{a}, 1}$, Svetoslav D. Todorov ${ }^{\mathrm{b}, 2}$, Carol A. van Reenen ${ }^{\mathrm{b}, 2}$, Tim Hogg ${ }^{\mathrm{a}, 1}$, \\ Leon M.T. Dicks ${ }^{b, *}$, Paula Teixeira ${ }^{a, 1}$ \\ ${ }^{a}$ Escola Superior de Biotecnologia, Universidade Católica Portuguesa, Rua Dr. António Bernardino de Almeida, 4200-072 Porto, Portugal \\ ${ }^{\mathrm{b}}$ Department of Microbiology, Stellenbosch University, Stellenbosch, Private Bag X1, Matieland 7602, South Africa
}

Keywords: Pediocin-like bacteriocins; Pediococcus acidilactici; Alheira fermented sausage

\begin{abstract}
Lactic acid bacteria were isolated from "Alheira" sausages that have been sampled from different regions in Portugal. The sausages were produced according to different recipes and with traditional starter cultures. Two isolates (HA-6111-2 and HA-5692-3) from different sausages were identified as strains of Pediococcus acidilactici. Each strain produces a bacteriocin, designated as bacHA-6111-2 and bacHA-5692-3. Both bacteriocins are produced at low levels after $18 \mathrm{~h}$ of growth in MRS broth (3200 AU/ml against Enterococcus faecium HKLHS and 1600 AU/ml against Listeria innocua N27). BacHA-6111-2 and bacHA-5692-3 are between $3.5 \mathrm{kDa}$ and $6.5 \mathrm{kDa}$ in size, as determined by tricine-SDS-PAGE. Complete inactivation or significant reduction in antimicrobial activity was observed after treatment of cell-free supernatants with proteinase $\mathrm{K}$, pronase and trypsin. No change in activity was recorded when treated with catalase. Both bacteriocins are sensitive to treatment with Triton X-114 and Triton X-100, but resistant to Tween 20, Tween 80, SDS, Oxbile, NaCl, urea and EDTA. The bacteriocins remained stable after $2 \mathrm{~h}$ at $\mathrm{pH}$ 6.0. A decrease in antibacterial activity was recorded after $60 \mathrm{~min}$ at $100{ }^{\circ} \mathrm{C}$. After $60 \mathrm{~min}$ at $80{ }^{\circ} \mathrm{C}, 60{ }^{\circ} \mathrm{C}$ and $25^{\circ} \mathrm{C}$ the antibacterial activity against L. innocua N27 decreased by 25\%. Addition of bacHA-6111-2 and bacHA-5692-3 (1600 AU/ml) to a mid-log (5-h-old) culture of L. innocua N27 inhibited growth for $7 \mathrm{~h}$. Addition of the bacteriocins (3200 AU/ml) to a mid-log (5-h-old) culture of E. faecium HKLHS repressed cell growth. The bacteriocins did not adhere to the surface of the producer cells. Both strains contain a $1044 \mathrm{bp}$ DNA fragment corresponding in size to that recorded for pediocin PA-1. Sequencing of the fragments from both bacteriocins revealed homology to large sections of pedA (188 bp), pedB (338 bp) and pedC (524 bp) of pediocin PA-1 and the bacteriocins are considered similar to pediocin PA-1.
\end{abstract}

Introduction

Fermented meat products are part of the daily diet in rural areas of Portugal and have become very popular in urban centres. "Alheira" is a traditional fermented meat product typical of the Northern regions (Trás-os-Montes) in Portugal.

\footnotetext{
* Corresponding author. Tel.: +27 21808 5849; fax: +27 218085846 . E-mail addresses:1mtd@sun.ac.za (L.M.T. Dicks), paula@esb.ucp.pt (P. Teixeira).

${ }^{1}$ Tel.: +351225 580 001; fax: +351225 580111 .

${ }^{2}$ Tel.: +27 21808 5849; fax: +27 218085846 .
}

The specific characteristics of the product depend on the raw materials used, the agro-ecosystem of the production area, and the traditional production methods used. "Alheira" is produced from a combination of pork meat, pork lard, poultry, wheat bread and olive oil mixed with salt, garlic and spices. The paste is stuffed in casings made from animal products and is smoked for a maximum of 8 days. "Alheira" contains mainly lactic acid bacteria and Micrococcaceae. Some pathogens, such as Listeria monocytogenes, Salmonella spp. and Staphylococcus aureus are occasionally present (Ferreira et al., 2006).

Selected strains of lactic acid bacteria, used as starter cultures, may inhibit spoilage microorganisms by production 
of organic acids, hydrogen peroxide, diacetyl and bacteriocins. Strains of Lactococcus, Lactobacillus, Leuconostoc and Pediococcus spp. are the most commonly used starter cultures (Liepe, 1983; Stiles and Hastings, 1991). Although many strains of these species produce bacteriocins, only nisin produced by Lactococcus lactis subsp. lactis has GRAS (generally recognized as safe) status and has been approved by the USA FDA (Food and Drug Administration) as food preservative.

Pediococcus acidilactici, Pediococcus pentosaceus and Pediococcus parvulus isolated from meat produce various bacteriocins. Pediocin AcH (PA-1), produced by P. acidilactici, was the first thoroughly characterized class IIa bacteriocin (Bhunia et al., 1988; Pucci et al., 1988; Nieto-Lozano et al., 1992; Cintas et al., 1995). The same bacteriocin is also produced by strains of $P$. parvulus isolated from vegetables (Bennik et al., 1997) and a strain of Lactobacillus plantarum isolated from cheese (Ennahar et al., 1996; Loesner et al., 2003). Pediocin-like bacteriocins share 40 to $60 \%$ DNA homology (Eijsink et al., 1998) and are all active against L. monocytogenes (Aymerich et al., 1996; Cintas et al., 1998; Bennik et al., 1999; Guyonnet et al., 2000).

In this study, a class IIa pediocin-like bacteriocin produced by $P$. acidilactici HA-6111-2 and P. acidilactici HA-5692-3 isolated from "Alheira" is described.

\section{Materialas and methods}

\section{Screening for bacteriocin-producing lactic acid bacteria}

Lactic acid bacteria, isolated from "Alheira" sausages produced in different regions of Portugal and according to traditional recipes, were cultured in MRS broth (Biolab, Biolab Diagnostics, Midrand, South Africa) and screened for bacteriocin production according to the method described by Van Reenen et al. (1998). The target strains and their growth media are listed in Table 1. Antimicrobial activity was expressed as arbitrary units (AU) per ml. One AU is defined as the reciprocal of the highest dilution showing a clear zone of growth inhibition (Van Reenen et al., 1998). Cell-free supernatants with antimicrobial activity were treated with proteinase $\mathrm{K}(1 \mathrm{mg} / \mathrm{ml}$; Roche, Indianopolis, USA) to determine if activity is caused by the presence of a bacteriocin. All strains were stored at $-80{ }^{\circ} \mathrm{C}$ in the presence of $15 \%(\mathrm{v} / \mathrm{v})$ glycerol.

\footnotetext{
Notes to Table 1

$-=$ no activity, $+=$ zone larger than $2 \mathrm{~mm},+/-=$ zone smaller than $2 \mathrm{~mm}$

a Escola Superior de Biotecnologia, UCP, Porto, Portugal.

b Department of Microbiology, Stellenbosch University, Stellenbosch, South Africa.

${ }^{c}$ National Collection of Food Bacteria, Reading, UK

d American Type Culture Collection, Manassas, VA, USA.

e Deutsche Sammlung von Mikroorganismen und Zellkulturen GmbH, Braunschweig, Germany.

${ }^{\mathrm{f}}$ Laboratorium voor Microbiologie, Universiteit Gent, Gent, Belgium.

g Department of Microbiology, University of Western Cape, Cape Town, South Africa.

${ }^{\mathrm{h}}$ National Collection of Type Cultures, Central Public Laboratory Service, London, UK.
}

Table 1

Growth medium and incubation temperature of indicator strains and spectrum of antimicrobial activity recorded for bacteriocins HA-6111-2 and HA-5692-3

\begin{tabular}{|c|c|c|c|c|}
\hline Indicator strain & Origin & $\begin{array}{l}\text { Growth media } \\
\text { and temperature }\end{array}$ & $\begin{array}{l}\text { HA- } \\
6111-2\end{array}$ & $\begin{array}{l}\text { HA- } \\
5692-3\end{array}$ \\
\hline Lactobacillus brevis $25,54^{\mathrm{a}}$ & "Alheira" & $30^{\circ} \mathrm{C}, \mathrm{MRS}$ & - & - \\
\hline Lactobacillus curvatus DF38 ${ }^{\mathrm{b}}$ & Salami & $30^{\circ} \mathrm{C}$, MRS & - & - \\
\hline $\begin{array}{l}\text { Lactobacillus pentosus } \\
\quad \text { NCFB } 363^{\mathrm{Tc}}\end{array}$ & Unknown & $30^{\circ} \mathrm{C}$, MRS & - & - \\
\hline $\begin{array}{l}\text { L. pentosus } \mathrm{ST} 151 \mathrm{BR} \text {, } \\
\text { ST112BR }^{\mathrm{b}}\end{array}$ & $\begin{array}{l}\text { Barley } \\
\text { beer }\end{array}$ & $30^{\circ} \mathrm{C}$, MRS & - & - \\
\hline $\begin{array}{l}\text { Lactobacillus paraplantarum } \\
\text { ATCC } 700211^{\mathrm{T} d}\end{array}$ & $\begin{array}{l}\text { French } \\
\text { beer }\end{array}$ & $30^{\circ} \mathrm{C}$, MRS & - & - \\
\hline 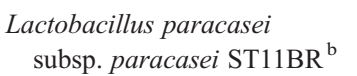 & $\begin{array}{l}\text { Barley } \\
\text { beer }\end{array}$ & $30^{\circ} \mathrm{C}$, MRS & - & - \\
\hline $\begin{array}{l}\text { Lactobacillus plantarum } \\
\text { AMA-K }{ }^{\mathrm{b}}\end{array}$ & Amasi & $30^{\circ} \mathrm{C}$, MRS & - & - \\
\hline L. plantarum $423^{\mathrm{b}}$ & $\begin{array}{l}\text { Sorghum } \\
\text { beer }\end{array}$ & $30^{\circ} \mathrm{C}$, MRS & - & - \\
\hline L. plantarum $\mathrm{ST} 8 \mathrm{KF}^{\mathrm{b}}$ & Kefir & $30^{\circ} \mathrm{C}$, MRS & - & - \\
\hline L. plantarum $\mathrm{ST} 13 \mathrm{BR}^{\mathrm{b}}$ & $\begin{array}{l}\text { Barley } \\
\text { beer }\end{array}$ & $30^{\circ} \mathrm{C}$, MRS & - & - \\
\hline $\begin{array}{l}\text { Lactobacillus rhamnosus } \\
\quad 50,10,78,56^{\mathrm{a}}\end{array}$ & "Alheira" & $30^{\circ} \mathrm{C}$, MRS & - & - \\
\hline $\begin{array}{l}\text { Lactobacillus sakei DSM } \\
20017^{\mathrm{e}}\end{array}$ & Meat & $30^{\circ} \mathrm{C}$, MRS & - & - \\
\hline L. sakei $36^{\mathrm{a}}$ & "Alheira" & $30^{\circ} \mathrm{C}$, MRS & - & - \\
\hline $\begin{array}{l}\text { Lactococcus lactis subsp } \\
\text { lactis HV219 }\end{array}$ & $\begin{array}{l}\text { Human } \\
\text { vagina }\end{array}$ & $30^{\circ} \mathrm{C}$, MRS & + & + \\
\hline Leuconostoc mesenteroides $23^{\text {a }}$ & "Alheira" & $30^{\circ} \mathrm{C}$, MRS & - & - \\
\hline Listeria innосиа LMG $13568^{\mathrm{f}}$ & Bovine & $37^{\circ} \mathrm{C}, \mathrm{BHI}$ & - & - \\
\hline L. inпосиа $\mathrm{N} 27^{\mathrm{g}}$ & Cheese & $37^{\circ} \mathrm{C}, \mathrm{BHI}$ & + & + \\
\hline $\begin{array}{l}\text { Listeria monocytogenes } \\
\quad 4855^{\text {a }}\end{array}$ & Unknown & $37^{\circ} \mathrm{C}, \mathrm{BHI}$ & + & + \\
\hline L. іппосиа 2030c, PHLS ${ }^{\text {a }}$ & Unknown & $37^{\circ} \mathrm{C}, \mathrm{BHI}$ & - & - \\
\hline L. monocytogenes $7973^{\mathrm{a}}$ & Unknown & $37^{\circ} \mathrm{C}, \mathrm{BHI}$ & - & - \\
\hline L. monocytogenes $\mathrm{Scott}^{\mathrm{a}}$ & $\begin{array}{l}\text { S moked } \\
\text { salmon }\end{array}$ & $37^{\circ} \mathrm{C}, \mathrm{BHI}$ & + & + \\
\hline L. monocytogenes $54^{\mathrm{a}}$ & Unknown & $37^{\circ} \mathrm{C}, \mathrm{BHI}$ & - & - \\
\hline $\begin{array}{l}\text { Listeria ivanovii subsp. } \\
\quad \text { ivanovii } \mathrm{NCTC} 11846^{\mathrm{h}}\end{array}$ & Unknown & $37^{\circ} \mathrm{C}, \mathrm{BHI}$ & + & + \\
\hline $\begin{array}{l}\text { Enterococcus faecalis } \\
\quad \text { ATCC } 29212^{\mathrm{d}}\end{array}$ & Urine & $37^{\circ} \mathrm{C}, \mathrm{BHI}$ & - & - \\
\hline E. faecalis FAIR E90 ${ }^{\mathrm{b}}$ & Piglets & $37^{\circ} \mathrm{C}, \mathrm{BHI}$ & - & - \\
\hline E. faecalis FAIR E80 ${ }^{\mathrm{b}}$ & Piglets & $37^{\circ} \mathrm{C}, \mathrm{BHI}$ & - & + \\
\hline E. faecalis FAIR E77, FA2 ${ }^{\text {b }}$ & Piglets & $37^{\circ} \mathrm{C}, \mathrm{BHI}$ & + & + \\
\hline $\begin{array}{l}\text { E. faecalis FAIR E } 88 \text {, } \\
\text { FAIR E92 }{ }^{\text {b }}\end{array}$ & Piglets & $37^{\circ} \mathrm{C}, \mathrm{BHI}$ & $+/-$ & $+/-$ \\
\hline $\begin{array}{l}\text { Enterococcus mundtii } \\
{\text { PTA- } 7278^{\mathrm{d}}}\end{array}$ & $\begin{array}{l}\text { Soy } \\
\text { beans }\end{array}$ & $37^{\circ} \mathrm{C}, \mathrm{BHI}$ & - & + \\
\hline $\begin{array}{l}\text { Enteroccocus faecium } \\
\text { HKLHS }^{\mathrm{b}}\end{array}$ & Piglets & $37^{\circ} \mathrm{C}, \mathrm{BHI}$ & + & + \\
\hline Enterococcus sp. $9,57^{\text {a }}$ & "Alheira" & $37^{\circ} \mathrm{C}, \mathrm{BHI}$ & + & + \\
\hline E. faecalis BFE1071 ${ }^{\mathrm{b}}$ & Piglets & $37^{\circ} \mathrm{C}, \mathrm{BHI}$ & - & - \\
\hline Escherichia coli $\mathrm{NCTC} 9001^{\mathrm{h}}$ & Urine & $37^{\circ} \mathrm{C}, \mathrm{BHI}$ & - & - \\
\hline E. coli $0: 157: \mathrm{H}^{\mathrm{a}}$ & Unknown & $37^{\circ} \mathrm{C}, \mathrm{BHI}$ & - & - \\
\hline $\begin{array}{l}\text { Staphylococcus aureus } \\
\text { ATCC } 29213^{\mathrm{d}}\end{array}$ & Wound & $37^{\circ} \mathrm{C}, \mathrm{BHI}$ & - & - \\
\hline Salmonella typhimurium $^{\mathrm{a}}$ & Unknown & $37^{\circ} \mathrm{C}, \mathrm{BHI}$ & - & - \\
\hline $\begin{array}{l}\text { Salmonella enteritidis } \\
\text { NCTC } 5188^{\mathrm{h}}\end{array}$ & Unknown & $37^{\circ} \mathrm{C}, \mathrm{BHI}$ & - & - \\
\hline $\begin{array}{l}\text { Streptococcus caprinus } \\
\text { ATCC } 700065^{\mathrm{d}}\end{array}$ & Goat & $37^{\circ} \mathrm{C}, \mathrm{BHI}$ & + & + \\
\hline $\begin{array}{l}\text { Streptococcus sp. } \\
\text { TL1, TL2R, TL2 } \mathrm{W}^{\mathrm{b}}\end{array}$ & Goat & $37^{\circ} \mathrm{C}, \mathrm{BHI}$ & + & + \\
\hline $\begin{array}{l}\text { Streptococcus macedonicus } \\
\text { ST91KM }\end{array}$ & $\begin{array}{l}\text { Goat } \\
\text { yogurt }\end{array}$ & $37^{\circ} \mathrm{C}, \mathrm{BHI}$ & - & - \\
\hline
\end{tabular}




\section{Identification of bacteriocin-producing strains}

Bacteriocin-producing strains were identified according to physiological and biochemical characteristics, as described by Schillinger and Lücke (1987). Further identification was by PCR with species-specific primers (PacF: CGA ACT TCC GTT AAT TGA TTA T and PuR: ACC TTG CGG TCG TAC TCC) according to the method described by Mora et al. (1997). Lambda DNA, digested with EcoR1 and HindIII (Roche, Indianopolis, USA) was used as marker.

Differentiation of the strains was by random amplification of polymorphic DNA (RAPD) PCR. Total DNA was isolated according to the method of Dellaglio et al. (1973). Primers M13 (5'-GAG GGT GGC GGT TCT-3') and D8635 (5'-GAG CGG CCA AAG GGA GCA GAC-3') were used (Huey and Hall, 1989). Amplification reactions were performed according to Andrighetto et al. (2001). The $25 \mu \mathrm{l}$ reaction volume contained $0.99 \mathrm{mM}$ primer M13, 1× PCR Buffer (MBI Fermentas, Mundolsheim, France), $2.5 \mathrm{mM} \mathrm{MgCl}_{2}$ (MBI Fermentas), $0.15 \mathrm{mM}$ dNTP (Abgene, Surrey, UK) and $1 \mathrm{U} \mathrm{Taq}$ DNA polymerase (MBI Fermentas). The second amplification contained $0.88 \mathrm{mM}$ primer D8635, $1 \times$ PCR Buffer, $2.5 \mathrm{mM} \mathrm{MgCl}_{2}$, $0.2 \mathrm{mM}$ dNTP and $1 \mathrm{U}$ Taq DNA polymerase. Amplification was in a DNA thermal cycler (My Cycler ${ }^{\mathrm{TM}}$ Thermal Cycler Firware, BioRad) as follows: initial denaturation at $94{ }^{\circ} \mathrm{C}$ for $2 \mathrm{~min}, 35$ cycles of $1 \mathrm{~min}$ per cycle at $94{ }^{\circ} \mathrm{C}$, and $1 \mathrm{~min}$ at $46.9^{\circ} \mathrm{C}$, followed by an increase to $72{ }^{\circ} \mathrm{C}$ over $90 \mathrm{~s}$. Extension of the amplified product was at $72{ }^{\circ} \mathrm{C}$ for $10 \mathrm{~min}$. The amplified products were separated by electrophoresis in $1.2 \%(\mathrm{w} / \mathrm{v})$ agarose gels in $1 \times$ TAE buffer ( $4.84 \mathrm{~g}$ Tris-base, $1.09 \mathrm{~g}$ glacial acetic, $0.29 \mathrm{~g}$ ethylenediaminetetraacetic acid, 11 distilled water) at $80 \mathrm{~V}$ for $2 \mathrm{~h}$. Gels were stained in TAE buffer containing $0.5 \mu \mathrm{g} / \mathrm{ml}$ ethidium bromide (Sigma Diagnostics, St. Louis, Mo., USA). A 100-bp DNA ladder (BioRad Laboratories, Richmond, CA) was used as a molecular weight marker. Banding patterns were analysed using Gel Compare, Version 4.1 (Applied Maths, Kortrijk, Belgium).

\section{Bacteriocin production during growth}

MRS broth (100 ml; Biolab) was inoculated with $1 \%$ (v/v) of an overnight culture and incubated at $37^{\circ} \mathrm{C}$. Changes in $\mathrm{pH}$ and optical density $(600 \mathrm{~nm})$ were recorded every hour for $24 \mathrm{~h}$. Bacteriocin activity $(\mathrm{AU} / \mathrm{ml})$ in the cell-free supernatant was recorded every $3 \mathrm{~h}$ for $24 \mathrm{~h}$, as described by Van Reenen et al. (1998). Listeria innocua N27 and Enterococcus faecium HKLHS were used as target strains.

\section{Molecular size of bacteriocins}

Strains were grown in MRS broth for $18 \mathrm{~h}$ at $37{ }^{\circ} \mathrm{C}$. The cells were harvested $\left(8000 \times g, 10 \mathrm{~min}, 4{ }^{\circ} \mathrm{C}\right)$ and bacteriocins precipitated from the cell-free supernatants with $40 \%$ saturated ammonium sulphate (Sambrook et al., 1989). The precipitate was re-suspended in one tenth-volume $25 \mathrm{mM}$ ammonium acetate buffer ( $\mathrm{pH}$ 6.5) and separated by tricine-SDS-PAGE, as described by Schägger and Von Jagow (1987). A low molecular weight marker with sizes ranging from 2.5 to $45 \mathrm{kDa}$ (Amersham Pharmacia Biotech Europe GmbH, Freiburg, Germany) was used. The gels were fixed and one half stained with Coomassie Brilliant Blue R250 (Saarchem, Krugersdorp, South Africa). The positions of the active bacteriocins were determined by overlaying the other half of the gel (not stained and extensively pre-washed with the sterile distilled water) with cells of $L$. innосиа N27 $\left(10^{6} \mathrm{CFU} / \mathrm{ml}\right)$, embedded in Brain Heart Infusion (BHI) agar $(0.7 \%$ agar w/v).

\section{Effect of enzymes, temperature, $\mathrm{pH}$, surfactants and pro- teaseinhibitorsonbacteriocinactivity}

Strains were grown in MRS broth for $18 \mathrm{~h}$ at $37^{\circ} \mathrm{C}$. The cells were harvested $\left(8000 \times g, 10 \mathrm{~min}, 4^{\circ} \mathrm{C}\right)$ and the cell-free supernatant adjusted to $\mathrm{pH} 6.0$ with $1 \mathrm{M} \mathrm{NaOH}$. One millilitre cell-free supernatant was incubated for $2 \mathrm{~h}$ in the presence of $1 \mathrm{mg} / \mathrm{ml}$ and $0.1 \mathrm{mg} / \mathrm{ml}$ of each of proteinase $\mathrm{K}$, pronase, papain, pepsin and trypsin (Boehringer Mannheim $\mathrm{GmbH}$, Germany), $\alpha$-amylase (Sigma) and catalase (Boehringer Mannheim), respectively. Antimicrobial activity was monitored by using the agar-spot test method (Van Reenen et al., 1998). In a separate experiment, $1 \%(\mathrm{w} / \mathrm{v})$ sodium dodecyl sulphate (SDS), Tween 20, Tween 80, urea, Triton X-114, Triton X-100, Oxbile and $\mathrm{NaCl}$ were added to bacteriocin-containing cellfree supernatants. EDTA was added to cell-free supernatants to yield final concentrations of $0.1,2.0$ and $5.0 \mathrm{mM}$. Untreated cell-free supernatants and detergents at these respective concentrations in water were used as controls. All samples were incubated at $37{ }^{\circ} \mathrm{C}$ for $5 \mathrm{~h}$ and then tested for antimicrobial activity by using the agar-spot test method as described before.

The effect of $\mathrm{pH}$ on the activity of bacteriocins was tested by adjusting cell-free supernatants from $\mathrm{pH} 2.0$ to 12.0 (at increments of two $\mathrm{pH}$ units) with sterile $1 \mathrm{M} \mathrm{NaOH}$ or $1 \mathrm{M} \mathrm{HCl}$. After $1 \mathrm{~h}$ of incubation at room temperature $\left(25^{\circ} \mathrm{C}\right)$, the samples were re-adjusted to $\mathrm{pH} 6.5$ with sterile $1 \mathrm{M} \mathrm{NaOH}$ or $1 \mathrm{M} \mathrm{HCl}$ and tested for antimicrobial activity by using the agarspot test method. L. innocua $\mathrm{N} 27$ and E. faecium HKLHS were used as target strains. The effect of temperature on bacteriocin activity was tested by incubating cell-free supernatants, adjusted to $\mathrm{pH} 7.0$ at $4,25,30,37,45,60,80$, and $100{ }^{\circ} \mathrm{C}$, respectively, for 60 and $120 \mathrm{~min}$. Bacteriocin activity was also tested after $20 \mathrm{~min}$ at $121{ }^{\circ} \mathrm{C}$. The agar-spot test method was used in all tests. L. innocua $\mathrm{N} 27$ and E. faecium HKLHS served as target strains.

\section{Cell lysis}

Twenty millilitres of a bacteriocin-containing cell-free supernatant (1600 AU/ml, pH 6.0) was filter-sterilized and added to $100 \mathrm{ml}$ early exponential phase (5-h-old) cultures of L. innocua N27 and E. faecium HKLHS, respectively. Optical density readings at $600 \mathrm{~nm}$ were taken every hour for $13 \mathrm{~h}$.

In a separate experiment, 18-h-old cultures of E. faecium HKLHS and L. іппосиа N27, respectively, were harvested 
$\left(5000 \times g, 5 \mathrm{~min}, 4^{\circ} \mathrm{C}\right.$ ), washed twice with sterile saline water and re-suspended in $10 \mathrm{ml}$. Equal volumes of the cell suspensions and filter-sterilized $\left(0.20 \mu \mathrm{m}\right.$, Minisart ${ }^{\circledR}$, Sartorius $)$ bacHA-6111-2 containing cell-free supernatant were mixed. Viable cell numbers were determined before and after incubation for $1 \mathrm{~h}$ at $37^{\circ} \mathrm{C}$ by plating onto MRS agar (Biolab). The experiment was repeated with bacHA-5692-3. Cell suspensions of E. faecium HKLHS and L. innocua N27 without added bacteriocins served as controls.

\section{Adsorption studies}

Adsorption of bacteriocins to producer cells was studied according to the method described by Yang et al. (1992). Bacteriocin-producing cells were cultured for $18 \mathrm{~h}$ at $37{ }^{\circ} \mathrm{C}$. The $\mathrm{pH}$ of the culture was adjusted to 6.0 with $1 \mathrm{M} \mathrm{NaOH}$ to allow maximal absorption of the bacteriocin to the producer cells. The cells were then harvested $\left(12,000 \times g, 15 \mathrm{~min}, 4^{\circ} \mathrm{C}\right)$ and washed with sterile $0.1 \mathrm{M}$ phosphate buffer ( $\mathrm{pH}$ 6.5). The pellet was re-suspended in $10 \mathrm{ml} 100 \mathrm{mM} \mathrm{NaCl}(\mathrm{pH} 2.0)$ and agitated for $1 \mathrm{~h}$ at $4{ }^{\circ} \mathrm{C}$ to allow delaminating bacteriocin from the cells. The cells were then harvested $(12,000 \times g, 15 \mathrm{~min}$, $4{ }^{\circ} \mathrm{C}$ ), the cell-free supernatant neutralized to $\mathrm{pH} 7.0$ with sterile $1 \mathrm{M} \mathrm{NaOH}$ and tested for bacteriocin activity as described before.

\section{Partial purification}

Bacteriocin-producing strains were cultured in $400 \mathrm{ml}$ MRS broth at $37^{\circ} \mathrm{C}$ until early stationary-phase (18-h-old cultures). Cells were harvested $\left(12,000 \times g, 20 \mathrm{~min}, 4^{\circ} \mathrm{C}\right)$ and ammonium sulphate gradually added to the supernatant to $40 \%$ saturation. After $4 \mathrm{~h}$ of slow stirring at $4{ }^{\circ} \mathrm{C}$, the proteins were harvested $\left(12,000 \times g, 1 \mathrm{~h}, 4^{\circ} \mathrm{C}\right)$. Precipitated proteins in the pellet and floating on the surface were collected and solubilized in $25 \mathrm{mM}$ ammonium acetate buffer ( $\mathrm{pH}$ 6.5). All samples were stored at $-20{ }^{\circ} \mathrm{C}$.

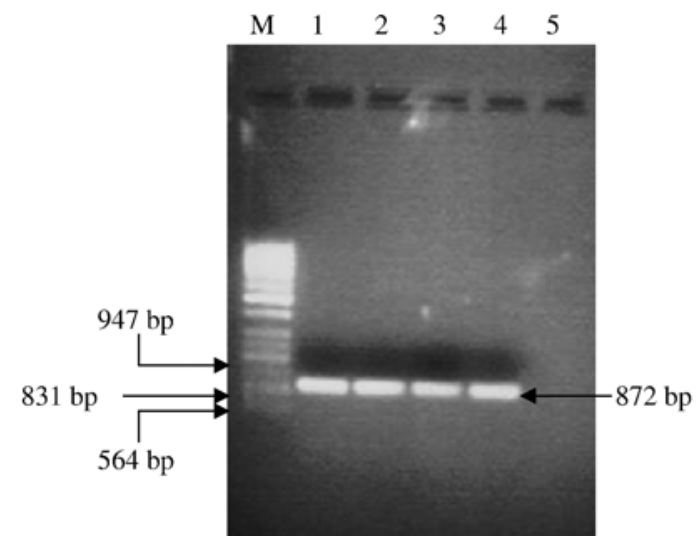

Fig. 1. Amplification with species-specific primers PacF and PuR yielded a 872 bp fragment characteristic for $P$. acidilactici. Lane 1: strain HA-6111-2; lane 2: strain HA-5692-3; lanes 3 and 4: P. acidilactici ATCC 12697; lane 5: P. pentosaceus ATCC 13561; lane M: $\lambda$, digested with EcoRI and HindIII.

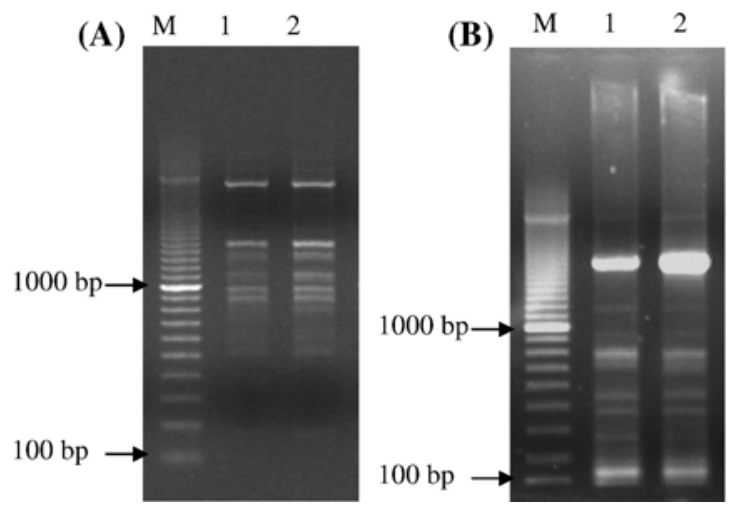

Fig. 2. Differentiation between strains HA-6111-2 and HA-5692-3 by RAPDPCR with primers M13 (A) and D8635 (B). Lane 1: strain HA-6111-2; lane 2 strain HA-5692-3; lane M: DNA molecular size markers (100 bp ladder).

\section{Identification of genes encoding bacteriocin production}

DNA was isolated according to the method of Dellaglio et al. (1973). Primers Pedpro (5'-CAA GAT CGT TAA CCA GTT T- $\left.3^{\prime}\right)$ and Ped 1041 ( $5^{\prime}$-CCG TTG TTC CCA TAG TCT AA- $3^{\prime}$ ) were designed from the operon encoding pediocin PA-1 (accession number M83924) and synthesised by Genosys Biotechnologies (Europe) Ltd. (Cambridgeshire, United Kingdom). PCR reactions were performed using a GeneAmp ${ }^{\circledR}$ PCR Instrument System 9700 (Applied Biosystems, Foster City, USA). The following conditions were used: an initial denaturation step of $94^{\circ} \mathrm{C}$ for $1 \mathrm{~min}$, followed by 35 cycles of $1 \mathrm{~min}$ at $94{ }^{\circ} \mathrm{C}, 30 \mathrm{~s}$ at $50{ }^{\circ} \mathrm{C}$ and $1 \mathrm{~min}$ at $72{ }^{\circ} \mathrm{C}$, and final extension at $72{ }^{\circ} \mathrm{C}$ for $5 \mathrm{~min}$. The amplified product was visualized in a $0.8 \%(\mathrm{w} / \mathrm{v})$ agarose gel stained with ethidium bromide. For each strain, a band corresponding to the correct size was purified from the gel using the QIAquick PCR purification kit according to the instructions of the manufacturer (QIAGEN $\mathrm{GmbH})$. Products were ligated into pGEM-T ${ }^{\circledR}$ Easy Vector (Promega, Madison, USA) and transformed into E. coli $\mathrm{DH} 5 \alpha$ according to the instructions of the manufacturer. Plasmids were isolated using a QIAGEN Plasmid Mini Kit and fragments sequenced on an automatic sequencer (ABI Genetic Analyzer 3130XI, Applied Biosystems) using bigdye terminator chemistry (Biosystem, Wanington, England). Sequences were analysed using DNAMAN for Windows ${ }^{\circledR}$ (Lynnon Biosoft, Quebec, Canada).

\section{Results and discussion}

Strains HA-6111-2 and HA-5692-3, isolated from "Alheira" produced by different companies, were identified as $P$. acidilactici by physiological and biochemical characteristics. The majority of lactic acid bacteria isolated from "Alheira" were identified as enterococci, present at levels of approximately $10^{7} \mathrm{cfu} / \mathrm{ml}$ (Ferreira et al., 2006). Little is known about the presence of pediococci in the product. The cells formed tetrads and displayed carbohydrate fermentation reactions typical to that recorded for $P$. acidilactici (not shown). Amplification with species-specific primers ( $\mathrm{PacF}$ and $\mathrm{PuR}$ ) yielded 

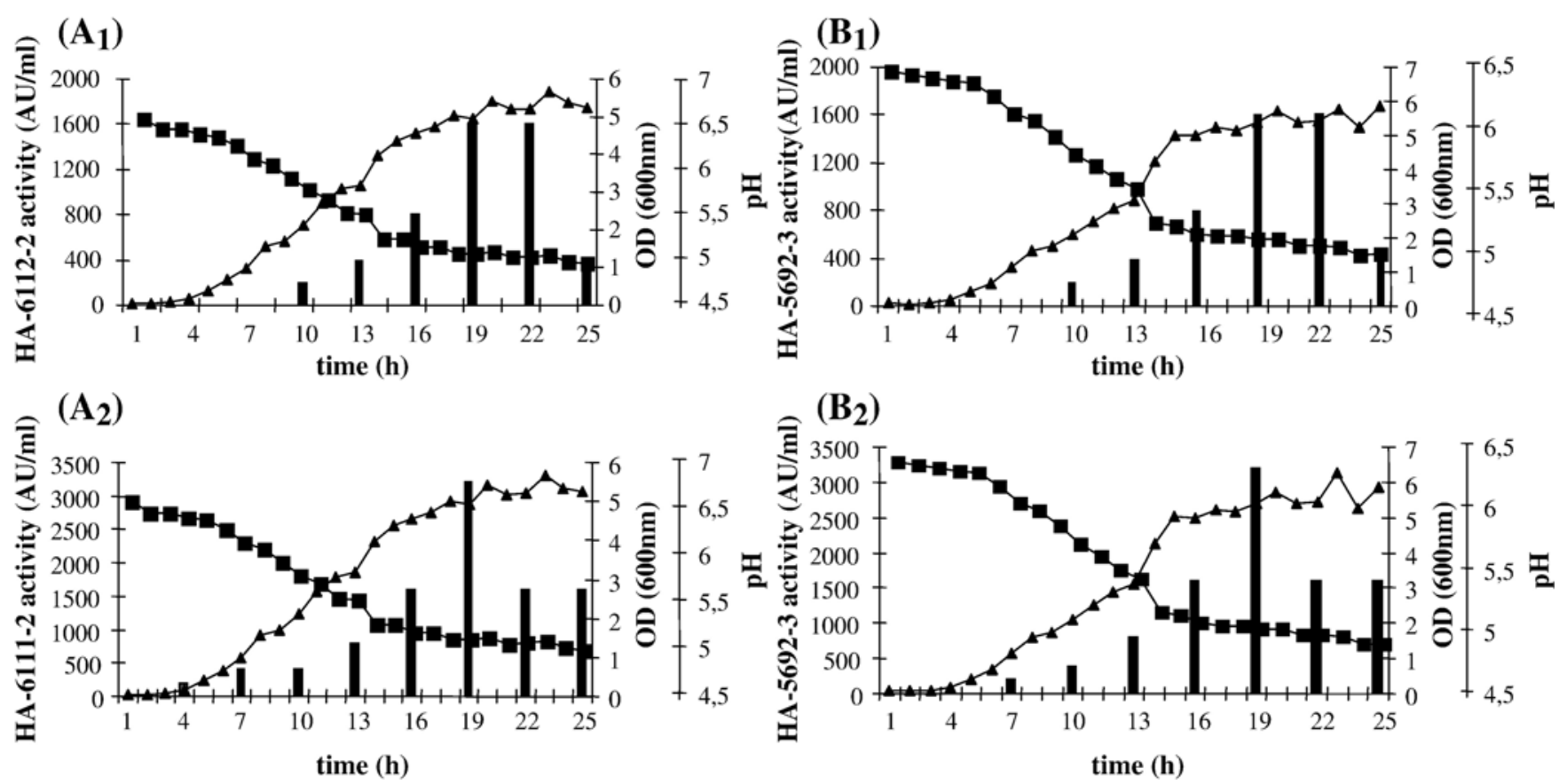

Fig. 3. Production of bacteriocins HA-6111-2 (graph A) and HA-5692-3 (graph B) in MRS broth (pH 6.4) at $37^{\circ} \mathrm{C}$. Antimicrobial activity of cell-free supernatants is presented as AU/ml (bars). 1: Sensitive strain L. inoccua N27; 2: sensitive strain E. faecium HKLHS. Changes in optical density $(\boldsymbol{\Delta})$ and $\mathrm{pH}(\boldsymbol{\square})$ are indicated.

a 872 bp fragment (Fig. 1), characteristic for the species. The RAPD-PCR banding patterns of the two strains were identical (Fig. 2).

The cell-free supernatant of strains HA-6111-2 and HA5692-3 inhibited the growth of L. lactis subsp. lactis; L. monocytogenes ScottA, 4855 and 54; L. innocua N27; L. ivanovii subsp. ivanovii NCTC 11846; E. faecalis FAIR E77. FAIR E88. FAIR E92 and FA2; Enterococcus sp. 9 and 57 (isolated from "Alheira"); Streptococcus sp. TL1, TL2R and TL2W; and Streptococcus caprinus ATCC 700065 (Table 1) E. faecium HKLHS; E. faecalis FAIR E80 and E. mundtii PTA-7278 were inhibited by strain HA-5692-3 and not by strain HA-6111-2. No antimicrobial activity was recorded against Gram-negative bacteria. The broad spectrum of antimicrobial activity recorded against Gram-positive bacteria is characteristic of many class IIa bacteriocins. The activity of pediocin PA-1 against $L$. monocytogenes is particularly relevant (Rodríguez et al., 2002). Activity against Gram-negative bacteria is an unusual phenomenon and has so far only been reported for thermophylin 81, produced by Streptococcus thermophylus, bacteriocins produced by L. paracasei subsp. paracasei L126 and L134, a bacteriocin produced by $L$. lactis KCA2386, and plantaricin 35d produced by L. plantarum (Ivanova et al., 1998; Ko and Ahn, 2000; Caridi, 2002; Messi et al., 2001). The structure and

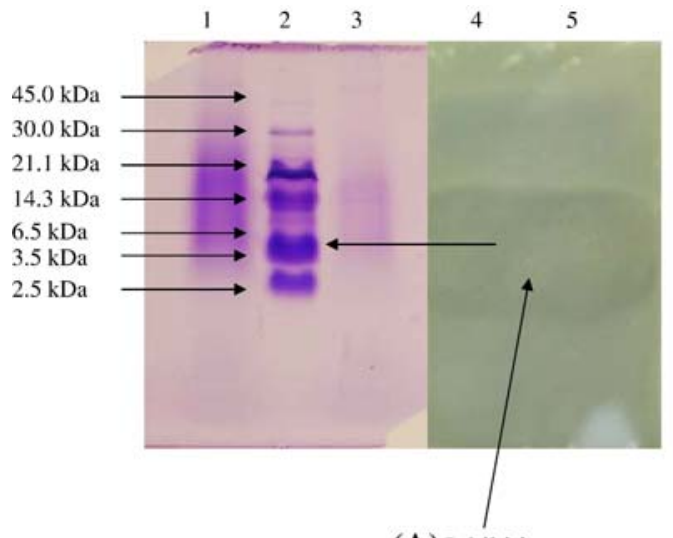

(A) Inhibition zone against L. innocua

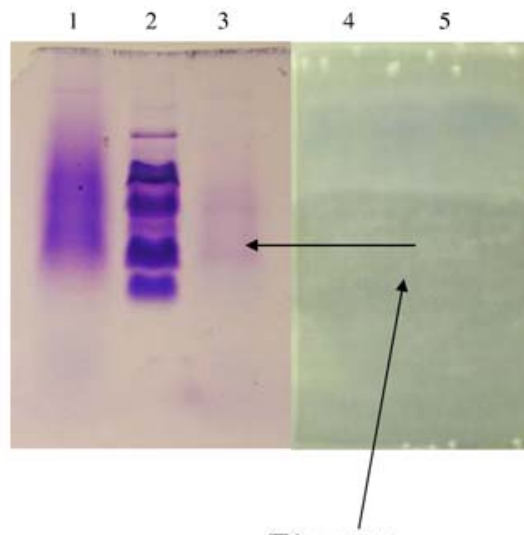

(B) Inhibition zone against L. innocua

Fig. 4. Tricine-SDS-PAGE of bacteriocins HA-6111-2 (A) and HA-5692-3 (B). Lane 1: peptide bands stained with Coomassie Blue R250 (40\% ammonium sulphate saturated); lane 2: molecular mass marker; lane 3: peptide bands stained with Coomassie Blue R250 (60\% ammonium sulphate saturated); lane 4: zone of growth inhibition, corresponding to the position of the peptide bands in lane 1; lane 5: zone of growth inhibition, corresponding to the position of the peptide bands in lane 3 . The gel in lanes 4 and 5 was covered with viable cells of $L$. innocua $\mathrm{N} 27$ (approx. $10^{6} \mathrm{CFU} / \mathrm{ml}$ ), imbedded in BHI agar. Incubation was at $37^{\circ} \mathrm{C}$ for $24 \mathrm{~h}$. 
composition of the outer membrane of Gram-negative bacteria does not allow access of pediocin to the cytoplasmic membrane. However, many Gram-negative organisms, (e.g. Salmonella typhimurium, Escherichia coli, Serratia liquefaciens and Pseudomonas fluorescens) are sensitive to pediocin PA-1 after sublethal injuries such as freezing, gentle heating, exposure to lactic acid or EDTA, and hydrostatic-pressure pasteurization to the outer membrane (Kalchayanand et al., 1992). Only a few $P$. pentosaceus strains are inhibitory to Gram-negative organisms (Spelhaug and Harlander, 1989). P. damnosus and P. pentosaceus isolated from beer exhibit antibacterial activity against a range of Gram-negative organisms (Skytta et al., 1993). Pediocin PA-1 from $P$. acidilactici PAC 1.0 adsorbed to both sensitive and resistant indicator strains (Gonzalez and Kunka, 1987; Pucci et al., 1988). Pediocin AcH from P. acidilactici binds to non-specific receptors, probably lipoteichoic acid. When present in high concentrations, the molecules bind to specific receptor(s) and change the integrity of the membrane (Bhunia et al., 1991).

BacHA-6111-2 and bacHA-5692-3 were produced at maximum levels (3200 AU/ml against E. faecium HKLHS and $1600 \mathrm{AU} / \mathrm{ml}$ against L. innocua N27) after $18 \mathrm{~h}$ of growth in MRS broth (Fig. 3A and B). During the first $24 \mathrm{~h}$ of growth, the medium $\mathrm{pH}$ of strain HA-6111-2 decreased from 6.51 to 4.95 and the cell density increased from 0.05 to 5.45 (dilution factor taken into account) (Fig. 3A). Low levels of bacHA-6111-2 activity (approximately $200 \mathrm{AU} / \mathrm{ml}$ against L. innocua N27) were recorded after $9 \mathrm{~h}$ of growth in MRS broth. Identical results were obtained when cells were grown at $30{ }^{\circ} \mathrm{C}$ and $37{ }^{\circ} \mathrm{C}$. This is in agreement with the results recorded for pediocin PA-1 (Ray, 1992). Optimal levels of pediocin PA-1 were recorded in growth media that supported high biomass production, e.g. MRS and TGE (tryptone glucose extract) (Biswas et al., 1991; Ray, 1992; Yang and Ray, 1994). All further experiments were conducted at $37^{\circ} \mathrm{C}$.

Maximal activity of bacHA-6111-2 (1600 AU/ml) was recorded after $18 \mathrm{~h}$ in MRS broth at $\mathrm{pH}$ 5.1. Bacteriocin activity against E. faecium HKLHS was detected after $3 \mathrm{~h}$ at $\mathrm{pH} 6.34$ and maximal activity $(3200 \mathrm{AU} / \mathrm{ml})$ recorded after $18 \mathrm{~h}$ (Fig. 3B). Similar results were recorded for bacHA-5692-3. The culture $\mathrm{pH}$ decreased from 6.38 to 4.92 and the cell density increased from $\mathrm{OD}_{600 \mathrm{~nm}} 0.074$ to 5.85 (dilution factor taken into account). Maximal activity was recorded at $\mathrm{pH} 5.05$. The constant bacteriocin activity levels recorded at $\mathrm{pH}$ values below 4.5 suggest that production is blocked (Todorov and Dicks, 2005b). Genetic studies on the expression of the genes encoding bacteriocin production will have to be done to confirm the latter hypothesis.

BacHA-6111-2 and bacHA-5692-3 are between 3.5 and $6.5 \mathrm{kDa}$ in size, as determined by SDS-PAGE (Fig. 4). The small peptides shown in Fig. 4 are within the range of most bacteriocins reported for the genus Pediococcus. The molecular weight of pediocin PA-1, calculated from the amino acid sequence, is $4629 \mathrm{Da}$ (Henderson et al., 1992; Fimland et al., 1996).

Complete inactivation or significant reduction in antimicrobial activity was observed after treatment of the cell-free supernatant with proteinase $\mathrm{K}$, pronase and trypsin (Table 2). Treatment with papain at $0.1 \mathrm{mg} / \mathrm{ml}$ decreased the activity of bacHA-6111-2 by approximately 50\%. Treatment with pepsin $(1 \mathrm{mg} / \mathrm{ml})$ reduced the activity levels of the bacteriocins by more than $75 \%$, but only $25 \%$ with $0.1 \mathrm{mg} / \mathrm{ml}$, showing that the concentration is an important factor. No change in activity was recorded when treated with catalase (Table 2), indicating that $\mathrm{H}_{2} \mathrm{O}_{2}$ was not responsible for inhibition. Treatment with $\alpha-$ amylase did not change the antimicrobial activity (Table 2), suggesting that both bacteriocins were not glycosylated and thus similar to most other bacteriocins (De Vuyst and Vandamme, 1994). Leuconocin S, produced by Leuconostoc paramesenteroides (Lewus et al., 1992) and carnocin 54, produced by Leuconostoc carnosum (Keppler et al., 1994) are typical examples of amylase-sensitive bacteriocins. Pediocin PA-1 activity is unaffected by treatment with phospholipase $\mathrm{C}$, catalase, lysozyme, DNAses, RNAses or lipases, but is lost after incubation with proteolytic enzymes such as trypsin, papain, chymotrypsin, protease IV, protease XIV, protease XXIV, and

Table 2

Reduction of antimicrobial activity of bacteriocins HA-6111-2 and HA-5692-3 (expressed in percentage values) after incubation at different conditions

\begin{tabular}{|c|c|c|c|c|c|}
\hline & & \multicolumn{2}{|c|}{ HA-6111-2 } & \multicolumn{2}{|c|}{ HA-5692-3 } \\
\hline & & $\begin{array}{l}L . \\
\text { innocua } \\
\text { N27 }\end{array}$ & $\begin{array}{l}E . \\
\text { faecium } \\
\text { HKLHS }\end{array}$ & $\begin{array}{l}L . \\
\text { innocua } \\
\mathrm{N} 27\end{array}$ & $\begin{array}{l}E . \\
\text { faecium } \\
\text { HKLHs }\end{array}$ \\
\hline \multirow[t]{6}{*}{$\mathrm{pH}$} & 2 & $50 \%$ & $50 \%$ & $50 \%$ & $25 \%$ \\
\hline & 4 & $25 \%$ & $25 \%$ & $25 \%$ & $25 \%$ \\
\hline & 6 & $0 \%$ & $0 \%$ & $0 \%$ & $0 \%$ \\
\hline & 8 & $50 \%$ & $25 \%$ & $50 \%$ & $50 \%$ \\
\hline & 10 & $75 \%$ & $50 \%$ & $75 \%$ & $50 \%$ \\
\hline & 12 & $100 \%$ & $100 \%$ & $100 \%$ & $75 \%$ \\
\hline \multirow[t]{8}{*}{ Temperature } & $4{ }^{\circ} \mathrm{C}$ & $0 \%$ & $25 \%$ & $0 \%$ & $25 \%$ \\
\hline & $25^{\circ} \mathrm{C}$ & $25 \%$ & $25 \%$ & $0 \%$ & $25 \%$ \\
\hline & $30^{\circ} \mathrm{C}$ and $37^{\circ} \mathrm{C}$ & $0 \%$ & $0 \%$ & $0 \%$ & $0 \%$ \\
\hline & $45^{\circ} \mathrm{C}$ & $25 \%$ & $0 \%$ & $0 \%$ & $25 \%$ \\
\hline & $60^{\circ} \mathrm{C}$ & $25 \%$ & $0 \%$ & $25 \%$ & $25 \%$ \\
\hline & $80^{\circ} \mathrm{C}$ & $25 \%$ & $0 \%$ & $25 \%$ & $50 \%$ \\
\hline & $100^{\circ} \mathrm{C}$ & $50 \%$ & $50 \%$ & $50 \%$ & $75 \%$ \\
\hline & $121^{\circ} \mathrm{C}$ & $100 \%$ & $100 \%$ & $100 \%$ & $100 \%$ \\
\hline \multirow[t]{20}{*}{ Enzymes } & Proteinase & $100 \%$ & $100 \%$ & $100 \%$ & $100 \%$ \\
\hline & $\mathrm{K}_{1.0}$ and $0.1 \mathrm{mg} / \mathrm{ml}$ & & & & \\
\hline & Pronase $_{1.0}$ and $0.1 \mathrm{mg} / \mathrm{ml}$ & $100 \%$ & $100 \%$ & $100 \%$ & $100 \%$ \\
\hline & Papain $_{1.0} \mathrm{mg} / \mathrm{ml}$ & $100 \%$ & $100 \%$ & $100 \%$ & $100 \%$ \\
\hline & Papain $_{0.1 \text { mg/ml }}$ & $50 \%$ & $50 \%$ & $100 \%$ & $100 \%$ \\
\hline & Pepsin $_{1.0 \mathrm{mg} / \mathrm{ml}}$ & $100 \%$ & $100 \%$ & $75 \%$ & $75 \%$ \\
\hline & Pepsin $0.1 \mathrm{mg} / \mathrm{ml}$ & $25 \%$ & $25 \%$ & $0 \%$ & $0 \%$ \\
\hline & Trypsin $_{1.0}$ and $0.1 \mathrm{mg} / \mathrm{ml}$ & $100 \%$ & $100 \%$ & $100 \%$ & $100 \%$ \\
\hline & $\alpha$-amylase $e_{1.0 \mathrm{mg} / \mathrm{ml}}$ & $0 \%$ & $25 \%$ & $25 \%$ & $25 \%$ \\
\hline & $\alpha$-amylase $0.1 \mathrm{mg} / \mathrm{ml}$ & $0 \%$ & $0 \%$ & $0 \%$ & $0 \%$ \\
\hline & Catalase $_{1.0}$ and $0.1 \mathrm{mg} / \mathrm{ml}$ & $0 \%$ & $25 \%$ & $0 \%$ & $25 \%$ \\
\hline & Tween 20 and Tween & $0 \%$ & $0 \%$ & $0 \%$ & $0 \%$ \\
\hline & $80_{0.01 \mathrm{~g} / \mathrm{ml}}$ & & & & \\
\hline & Triton X-114 and & $100 \%$ & $50 \%$ & $100 \%$ & $50 \%$ \\
\hline & Triton X-100 $0.01 \mathrm{~g} / \mathrm{ml}$ & & & & \\
\hline & $\mathrm{SDS}_{0.01 \mathrm{~g} / \mathrm{ml}}$ & $0 \%$ & $0 \%$ & $0 \%$ & $0 \%$ \\
\hline & $\mathrm{EDTA}_{0.1 \mathrm{mM}}$ & $0 \%$ & $0 \%$ & $0 \%$ & $0 \%$ \\
\hline & $\mathrm{EDTA}_{5.0 \mathrm{mM}}$ & $0 \%$ & $0 \%$ & $0 \%$ & $0 \%$ \\
\hline & Oxbile $_{0.01 \mathrm{~g} / \mathrm{ml}}$ & $0 \%$ & $0 \%$ & $0 \%$ & $0 \%$ \\
\hline & Urea and $\mathrm{NaCl}_{0.01} \mathrm{~g} / \mathrm{ml}$ & $0 \%$ & $0 \%$ & $0 \%$ & $0 \%$ \\
\hline
\end{tabular}


proteinase K (Gonzalez and Kunka, 1987; Bhunia et al., 1988; Ray et al., 1989).

Both bacteriocins are sensitive to treatment with $1 \%(\mathrm{~m} / \mathrm{v}$, final concentration), Triton X-114 and Triton X-100 (Table 2). However, treatment with Tween 20, Tween 80, SDS, Oxbile, $\mathrm{NaCl}$ and urea at $1 \%(\mathrm{~m} / \mathrm{v})$ or EDTA $(0.1 \mathrm{mM}, 2.0 \mathrm{mM}$ or $5.0 \mathrm{mM}$ ) had no affect on antimicrobial activity (Table 2). Similar results were recorded for plantaricin 423 (Verellen et al., 1998), pediocin AcH (Biswas et al., 1991), lactacin B (Barefoot and Klaenhammer, 1984) and lactocin 705 (Vignolo et al., 1995). $\mathrm{NaCl}$ concentrations of $0.1 \mathrm{M}$ were used to study the release of pediocin AcH (identical to PA-1) from the surface of the producer cells (Ray, 1994). Even in the presence of 1.0 M $\mathrm{NaCl}$ the activity was not affected (Ray, 1994). Bacteriocins HA-6111-2 and HA-5692-3 remained stable after incubation for $2 \mathrm{~h}$ at $\mathrm{pH} 6.0$ (Table 2). Antimicrobial activity was reduced at $\mathrm{pH}$ values below 5.0 and above 7.0 (Table 2), suggesting that the peptides are sensitive to acidic and alkaline conditions. This corresponded to the $\mathrm{pH}$ stability reported for pediocin PA-1 (Gonzalez and Kunka, 1987; Bhunia et al., 1988). A decrease in antibacterial activity was recorded after $60 \mathrm{~min}$ at $100{ }^{\circ} \mathrm{C}$, similar to that recorded for pediocin PA-1 produced by $P$. acidilactici (Rodríguez et al., 2002).

Addition of bacHA-6111-2 and bacHA-5692-3 (1600 AU/ml) to a mid- $\log \left(5\right.$-h-old) culture of $L$. innocua $\mathrm{N} 27\left(\mathrm{OD}_{600 \mathrm{~nm}} \approx 0.2\right)$ inhibited the growth for $7 \mathrm{~h}$ (Fig. 5A). Addition of bacHA-6111-2 and bacHA-5692-3 (3200 AU/ml) to a mid-log (5-h-old) culture of $E$. faecium HKLHS $\left(\mathrm{OD}_{600 \mathrm{~nm}} \approx 0.3\right)$ repressed cell growth in a similar way (Fig. 5B). However both bacteriocins acted bactericidal to stationary-phase (18-h-old) cells of E. faecium
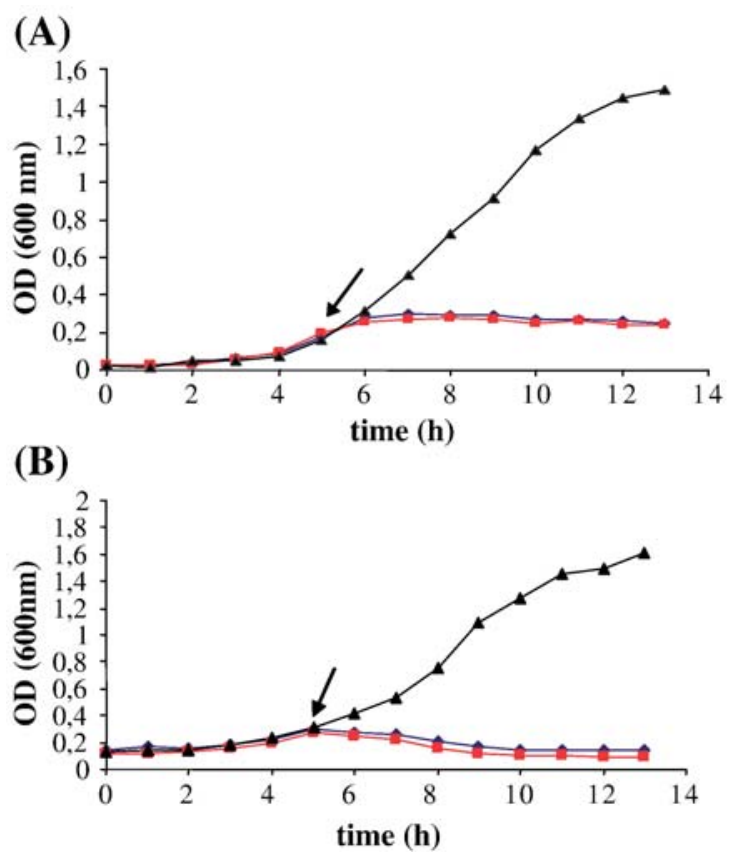

Fig. 5. Effect of bacteriocins HA-6111-2 (ם) and HA-5692-3 ( $)$ on (A) L. innocua $\mathrm{N} 27$ and (B) E. faecium HKLHS cultured at $37^{\circ} \mathrm{C}$. The symbol

(A) represents the growth of L. innocua N27 (A) and E. faecium HKLHS (B) without added bacteriocins (controls). The arrow indicates the point at which the bacteriocins were added $(5 \mathrm{~h})$.
Table 3

Effect of bacteriocins HA-6111-2 and HA-5692-3 on cell growth of L. innocua N27 and E. faecium HKLHS

\begin{tabular}{|c|c|c|c|c|}
\hline \multirow[b]{2}{*}{ Treatment: } & \multicolumn{2}{|c|}{ E. faecium HKLHS (CFU/ml) } & \multicolumn{2}{|c|}{ L. iпnосиа $\mathrm{N} 27$ (CFU/ml) } \\
\hline & $\begin{array}{l}\text { Before } \\
\text { treatment with } \\
\text { bacteriocin }\end{array}$ & $\begin{array}{l}\text { After } \\
\text { treatment with } \\
\text { bacteriocin }\end{array}$ & $\begin{array}{l}\text { Before } \\
\text { treatment with } \\
\text { bacteriocin }\end{array}$ & $\begin{array}{l}\text { After } \\
\text { treatment with } \\
\text { bacteriocin }\end{array}$ \\
\hline $\begin{array}{l}\text { BacHA- } \\
6111-2\end{array}$ & $1.5 \times 10^{10}$ & $<10$ & $1.0 \times 10^{11}$ & $2.8 \times 10^{7}$ \\
\hline $\begin{array}{l}\text { BacHA- } \\
5692-3\end{array}$ & $2.3 \times 10^{10}$ & $<10$ & $1.9 \times 10^{11}$ & $2.9 \times 10^{7}$ \\
\hline $\begin{array}{l}\text { None } \\
\qquad \text { (control) }\end{array}$ & $2.7 \times 10^{10}$ & $3.1 \times 10^{10}$ & $1.3 \times 10^{11}$ & $1.9 \times 10^{11}$ \\
\hline
\end{tabular}

HKLHS and bacteriostatic to stationary-phase (18-h-old) cells of L. innocua N27 (Table 3). No changes in cell numbers of E. faecium HKLHS and L. innocua N27 were recorded in the untreated (control) samples. Similar results were recorded in the treatment of the lower concentration of L. innocua N27 and E. faecium HKLHS by bacHA-6111-2 and bacHA-5692-3 (data not shown).

No bacteriocin activity was detected after treatment of strains HA-6111-2 and HA-5692-3 with $100 \mathrm{mM} \mathrm{NaCl} \mathrm{pH} 2.0$ (data not shown), suggesting that the bacteriocins did not adhere to the surface of the producer cells. Similar results were reported for plantaricin ST31 (Todorov et al., 1999), pediocin ST18 (Todorov and Dicks, 2005a) and bozacin B14 (Ivanova et al., 2000).

Pediocin PA-1 biosynthesis involves a DNA fragment of approximately $3.5 \mathrm{~kb}$, comprising the four genes pedA, pedB, pedC, and pedD (Marugg et al., 1992). Strains HA-6111-2 and HA-5692-3 have a 1044 bp DNA fragment identical to that recorded for pediocin PA-1 (Fig. 6). Sequencing of the $1044 \mathrm{bp}$ fragments revealed homology to large sections of pedA (bp 1076-1264), pedB (1302-1640) and pedC (bp 1664-2188) of pediocin PA-1 (Genbank accession number M83924; Marugg et al., 1992). Bacteriocins bacHA-6111-2 and bacHA-5692-3 are thus considered similar to pediocin PA-1.

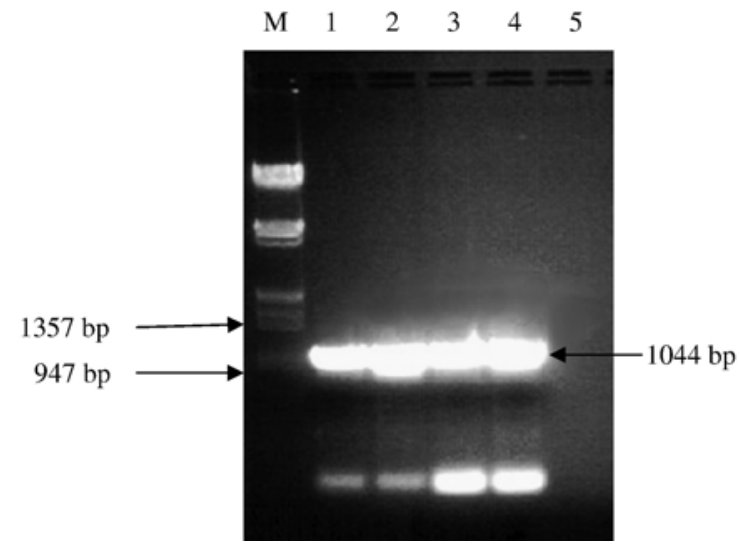

Fig. 6. Amplification of DNA of strains HA-6111-2 and HA-5692-3 with primers specific for pediocin PA-1 yielded a $1044 \mathrm{~kb}$ DNA fragments. Lane 1: strain HA-6111-2; lane 2: strain HA-5692-3; lanes 3 and 4: P. acidilactici ATCC 12697; lane 5: P. pentosaceus ATCC 13561; lane M: $\lambda$, digested with EcoRI and HindIII. 
Most bacteriocins (pediocin and pediocin-like) produced by Pediococcus spp. have antilisterial activity, are thermostable and fall within the size range from 2867 to $4685 \mathrm{Da}$ (Henderson et al., 1992; Daba et al., 1994; Fimland et al., 2002; Bauer et al., 2005; Diep et al., 2006). Pediocin AcH, produced by P. acidilactici $\mathrm{H}$, is identical to pediocin PA-1 produced by $P$. acidilactici PAC-1 (Gonzalez and Kunka, 1987; Bhunia et al., 1988; Henderson et al., 1992; Motlagh et al., 1992). Pediocin PA-1 is one of the best studied bacteriocins (Henderson et al. 1992; Marugg et al. 1992; Nieto-Lozano et al. 1992; Bukhtiyarova et al., 1994; Motlagh et al., 1994; Venema et al. 1995) and is considered a good biopreservative (Bhunia et al. 1988, 1991; Pucci et al. 1988; Yousef et al., 1991; Foegeding et al., 1992). BacHA-6111-2 and bacHA-5692-3 described in this study are similar to pediocin PA-1. Further research on the technological properties of the two strains (P. acidilactici HA-6111-2 and HA-5692-3) has to be done to determine if they can be used as commercial starter cultures for production of "Alheiras".

\section{Acknowledgements}

This work received financial support via project POCTI/ AGG/39587/2001, Fundação para a Ciência e Tecnologia (FCT)/ Fundo Europeu Desenvolvimento Regional (FEDER), Portugal and National Research Foundation (NRF), South Africa. Financial support for author $\mathrm{H}$. Albano was provided by $\mathrm{PhD}$ fellowship, SFRH/BD/13161/2003 (FCT).

\section{References}

Andrighetto, C., Zampese, L., Lombardi, A., 2001. RAPD-PCR characterization of lactobacilli isolated from artisanal meat plants and traditional fermented sausages of Veneto region (Italy). Letters in Applied Microbiology 33, 26-30.

Aymerich, T., Holo, H., Havarstein, L.S., Hugas, M., Garriga, M., Nes, I.F., 1996. Biochemical and genetic characterization of enterocin A from Enterococcus faecium, a new antilisterial bacteriocin in the pediocin family of bacteriocin. Applied and Environmental Microbiology 62, 1676-1682.

Barefoot, S.F., Klaenhammer, T.R., 1984. Purification and characterization of the Lactobacillus acidophilus bacteriocin lactacin B. Antimicrobial Agents and Chemotherapy 26, 328-334.

Bauer, R., Chikindas, M.L., Dicks, L.M.T., 2005. Purification, partial amino acid sequence and mode of action of pediocin PD-1, a bacteriocin produced by Pediococcus damnosus NCFB 1832. International Journal of Food Microbiology 101, 17-27.

Bennik, M.H., Smid, E.J., Gorris, L.G.M., 1997. Vegetable-associated Pediococcus parvulus produces pediocin PA-1. Applied and Environmental Microbiology 63, 2074-2076.

Bennik, M.H.J., van Overbeeck, W., Smid, E.J., Gorris, L.G.M., 1999. Biopreservation in modified atmosphere stored mungbean sprouts: the use of vegetable-associated bacteriocigenic lactic acid bacteria to control the growth of Listeria monocytogenes. Letters in Applied Microbiology 28, 226-232.

Bhunia, A.K., Johnson, M.C., Ray, B., 1988. Purification, characterization and microbial spectrum of a bacteriocin produced by Pediococcus acidilactici. Journal of Applied Bacteriology 65, 261-268.

Bhunia, A.K., Johnson, M.C., Ray, B., Kalchayanand, N., 1991. Mode of action of pediocin AcH from Pediococcus acidilactici $\mathrm{H}$ on sensitive bacterial strains. Journal of Applied Bacteriology 70, 25-30.

Biswas, S.R., Purbita, R., Johnson, M.C., Ray, B., 1991. Influence of growth conditions on the production of a bacteriocin, pediocin AcH, by Pediococcus acidilactici $\mathrm{H}$. Applied and Environmental Microbiology 57, 1265-1267.
Bukhtiyarova, M., Yang, R., Ray, R., 1994. Analysis of the pediocin AcH gene cluster from plasmid pSMB74 and its expression in a pediocin-negative Pediococcus acidilactici strain. Applied and Environmental Microbiology 60, 3045-3408.

Caridi, A., 2002. Selection of Escherichia coli - inhibiting strains of Lactobacillus paracasei subsp. paracasei. Journal of Applied Bacteriology 29, 303-308.

Cintas, L.M., Rodríguez, J.M., Fernández, M.F., Sletten, K., Nes, I.F., Hernández, P.E., Holo, H., 1995. Isolation and characterization of pediocin L50, a new bacteriocin from Pediococcus acidilactici with a broad inhibitory spectrum. Applied and Environmental Microbiology 61, 2643-2648.

Cintas, L.M., Casaus, P., Fernández, M.F., Hernández, P.E., 1998. Comparative antimicrobial activity of enterocin L50, pediocin PA-1, nisin A and lactocin $\mathrm{S}$ against spoilage and food-borne pathogenic bacteria. Food Microbiology $15,289-298$.

Daba, H., Lacroix, C., Huang, J., Simard, R.E., Lemieux, L., 1994. Simple method of purification and sequencing of a bacteriocin produced by $P e$ diococcus acidilactici UL5. Journal of Applied Bacteriology 77, 682-688.

De Vuyst, L., Vandamme, E.J., 1994. Bacteriocins of Lactic Acid Bacteria: Microbiology, Genetics and Applications. Blackie Academic and Professional, London, p. 539.

Dellaglio, F., Bottazzi, V., Troatelli, L.D., 1973. Deoxyribonucleic acid homology and base composition in some thermophylic lactobacilli. Journal of General Microbiology 74, 289-297.

Diep, D.B., Godager, L., Brede, D., Nes, I.F., 2006. Data mining and characterization of a novel pediocin-like bacteriocin system from the genome of Pediococcus pentosaceus ATCC 25745. Microbiology-SGM 152, 1649-1659.

Eijsink, V.G.H., Skeie, M., Middelhoven, P.H., Brurberg, M.B., Nes, I.F., 1998. Comparative studies of class IIa bacteriocins of lactic acid bacteria. Applied and Environmental Microbiology 64, 3275-3281.

Ennahar, S., Aoude-Werner, D., Sorokine, O., van Dorsselaer, A., Bringel, F., Hubert, J.C., Hasselmann, C., 1996. Production of pediocin AcH by Lactobacillus plantarum WHE92 isolated from cheese. Applied and Environmental Microbiology 62, 4381-4387.

Ferreira, V., Barbosa, J., Vendeiro, S., Mota, A., Silva, F., Monteiro, M.J., Hogg, T., Gibbs, P., Teixeira, P., 2006. Chemical and microbiological characterization of alheira: a typical Portuguese fermented sausage with particular reference to factors relating to food safety. Meat Science 73, 570-575.

Fimland, G., Blingsmo, O.R., Sletten, K., Jung, G., Nes, I.F., Nissen-Meyer, J., 1996. New biologically active hybrid bacteriocins constructed by combining regions from various pediocin-like bacteriocins: the C-terminal region is important for determining specificity. Applied and Environmental Microbiology 62, 3313-3318.

Fimland, G., Sletten, K., Nissen-Meyer, J., 2002. The complete amino acid sequence of the pediocin-like antimicrobial peptide leucocin C. Biochemical and Biophysical Research Communications 295, 826-827.

Foegeding, P.M., Thomas, A.B., Pilkington, D.H., Klaenhammer, T.R., 1992. Enhanced control of Listeria monocytogenes by in situ-produced pediocin during dry fermented sausage production. Applied and Environmental Microbiology 58, 884-890.

Gonzalez, C.F., Kunka, B.S., 1987. Plasmid associated bacteriocin production and sucrose fermentation in Pediococcus acidilactici. Applied and Environmental Microbiology 53, 2534-2538.

Guyonnet, D., Fremaux, C., Cenatiempo, Y., Berjeaud, M.J., 2000. Method for the rapid purification of class IIa bacteriocins and comparison of their activities. Applied and Environmental Microbiology 66, 1744-1748.

Henderson, J.T., Chopko, A.L., Dyck van Wassenaar, P.D., 1992. Purification and primary structure of pediocin PA-1, produced by Pediococcus acidilactici PAC-1.0. Archives of Biochemistry and Biophysics 295, 5-12.

Huey, B., Hall, J., 1989. Hypervariable DNA fingerprinting in Escherichia coli: minisatellite probe from bacteriophage M13. Journal of Bacteriology 171, $2528-2532$.

Ivanova, I., Miteva, V., Stefanova, T.S., Pantev, A., Budakov, I., Danova, S., Montcheva, P., Nikolova, I., Dousset, X., Boyaval, P., 1998. Characterization of a bacteriocin produced by Streptococcus thermophilus 81. International Journal of Food Microbiology 42, 147-158.

Ivanova, I., Kabadjova, P., Pantev, A., Danova, S., Dousset, X., 2000. Detection, purification and partial characterization of a novel bacteriocin substance 
produced by Lactococcus lactis susp. lactis B14 isolated from boza Bulgarian traditional cereal beverage. Biocatalalysis — Vestnik Moskovskogo Universiteta Kimia 41, 47-53.

Kalchayanand, N., Hanlin, M.B., Ray, B., 1992. Sublethal injury makes Gramnegative and resistant Gram-positive bacteria sensitive to the bacteriocins, pediocin AcH and nisin. Letters in Applied Microbiology 15, 239-243.

Keppler, K., Geisen, R., Holzaphel, W.H., 1994. An $\alpha$-amylase sensitive bacteriocin of Leuconostoc carnosum. Food Microbiology 11, 39-45.

Ko, S.-H., Ahn, C., 2000. Bacteriocin production by Lactococcus lactis KCA386 isolated from white kimachi. Food Science and Biotechnology 9, 263-269.

Lewus, C.B., Sun, S., Montville, J.T., 1992. Production of an $\alpha$-amylase bacteriocin by an atypical Leuconostoc paramesenteroides strain. Applied and Environmental Microbiology 58, 143-149.

Liepe, H.U., 1983. Starter cultures in meat production. In: Rehm, H.J., Reed Weinheim, G. (Eds.), Biotechnology. Verlag Chemie, pp. 399-424.

Loesner, M., Guenter, S., Stefan, S., Scherer, S., 2003. A pediocin producing Lactobacillus plantarum strain inhibits Listeria monocytogenes in a multispecies cheese surface microbial ripening consortium. Applied and Environmental Microbiology 69, 1854-1857.

Marugg, J.D., Gonzalez, C.F., Kunka, B.S., Ledeboer, A.M., Pucci, M.J., Toonen, M.Y., Walker, S.A., Zoetmudler, L.C.M., Vandenbergh, P.A., 1992. Cloning, expression, and nucleotide sequence of genes involved in the production of pediocin PA-1, a bacteriocin from Pediococcus acidilactici PAC1.0. Applied and Environmental Microbiology 58, 2360-2367.

Messi, P., Bondi, M., Sabia, C., Battini, R., Manicardi, G., 2001. Detection and preliminary characterization of a bacteriocin (plantaricin $35 \mathrm{~d}$ ) produced by a Lactobacillus plantarum strain. International Journal of Food Microbiology 64, 193-198.

Mora, D., Fortina, M.G., Parini, C., Manachini, P.L., 1997. Identification of Pediococcus acidilactici and Pediococcus pentosaceus based on 16S rRNA and $l d h D$ gene-targeted multiplex PCR analysis. FEMS Microbiology Letters 151, 231-236.

Motlagh, A.M., Bhunia, A.K., Szosteck, F., Hansen, T.R., Johnson, M.C., Ray, B., 1992. Nucleotide and amino acid sequence of pap-gene (pediocin AcH production) in Pediococcus acidilactici H. Letters in Applied Microbiology $15,45-48$.

Motlagh, A., Bukhtiyarova, M., Ray, B., 1994. Complete nucleotide sequence of pSMB74, plasmid encoding production of pediocin $\mathrm{AcH}$ in Pediococcus acidilactici. Letters in Applied Microbiology 18, 305-312.

Nieto-Lozano, J.C., Nissen-Meyer, J., Sletten, K., Pelaez, C., Nes, I.F., 1992. Purification and amino acid sequence of a bacteriocin produced by Pediococcus acidilactici. Journal of General Microbiology 138, 1985-1990.

Pucci, M.J., Vedamuthu, E.R., Kunka, B.S., Vandenbergh, P.A., 1988. Inhibition of Listeria monocytogenes by using bacteriocin PA-1 produced by Pediococcus acidilactici PAC1.0. Applied and Environmental Microbiology 54, 2349-2353.

Ray, B., 1992. Pediocin(s) of Pediococcus acidilactici as a food biopreservative. In: Ray, B., Daeschel, M. (Eds.), Food Biopreservatives of Microbial Origin. CRC Press, Boca Raton, pp. 265-322.

Ray, B., 1994. Pediocins of Pediococcus species. In: De Vuyst, L., Vandamme, E.J. (Eds.), Bacteriocins of Lactic Acid Bacteria. Chapman and Hall, Glasgow, pp. 465-495.

Ray, S.K., Kim, W.J., Johnson, M.C., Ray, B., 1989. Conjugal transfer of a plasmid encoding bacteriocin production and immunity in Pediococcus acidilactici H. Journal of Applied Bacteriology 66, 393-399.
Rodríguez, J.M., Martínez, M.I., Kok, J., 2002. Pediocin PA-1, a wide-spectrum bacteriocin from lactic acid bacteria. Critical Reviews in Food Science and Nutrition 42, 91-121.

Sambrook, J., Fritsch, E.F., Maniatis, T., 1989. Molecular Cloning: A Laboratory Manual. Cold Spring Harbour Laboratory Press, Cold Spring Harbor, NY.

Schägger, H., Von Jagow, G., 1987. Tricine-sodium dodecyl sulphate-polyacrylamide gel electrophoresis for the separation of protein in the range from 1 to $100 \mathrm{kDa}$. Analytical Biochemistry 166, 368-379.

Schillinger, U., Lücke, F.K., 1987. Identification of lactobacilli from meat and meat products. Food Microbiology 4, 199-208.

Skytta, E., Haikara, A., Mattila-Sandholm, T., 1993. Production and characterization of antibacterial compounds produced by Pediococcus damnosus and Pediococcus pentosaceus. Journal of Applied Bacteriology 74, 134-142.

Spelhaug, S.R., Harlander, S.K., 1989. Inhibition of food-borne pathogens by bacteriocins from Lactococcus lactis and Pediococcus pentosaceus. Journal of Food Protection 52, 856-862.

Stiles, M.E., Hastings, J.W., 1991. Bacteriocin production by lactic acid bacteria: potential for use in meat preservation. Trends in Food Science and Technology 2, 247-251.

Todorov, S.D., Dicks, L.M.T., 2005a. Pediocin ST18, an anti-listerial bacteriocin produced by Pediococcus pentosaceus ST18 isolated from boza, a traditional cereal beverage from Bulgaria. Process Biochemistry 40, 365-370.

Todorov, S.D., Dicks, L.M.T., 2005b. Effect of growth medium on bacteriocin production by Lactobacillus plantarum ST194BZ, a strain isolated from boza. Food Technology and Biotechnology 43, 165-173.

Todorov, S., Onno, B., Sorokin, O., Chobert, J.M., Ivanova, I., Dousset, X., 1999. Detection and characterization of a novel antibacterial substance produced by Lactobacillus plantarum ST31 isolated from sourdough. International Journal of Food Microbiology 48, 167-177.

Van Reenen, C.A., Dicks, L.M.T., Chikindas, M.L., 1998. Isolation, purification and partial characterization of plantaricin 423, a bacteriocin produced by Lactobacillus plantarum. Journal of Applied Microbiology 84, 1131-1137.

Venema, K., Kok, J., Marugg, J.D., Toonen, M.Y., Ledeboer, A.M., Venema, G., Chikindas, M.L., 1995. Functional analysis of the pediocin operon of $P e$ diococcus acidilactici PAC1.0: PedB is the immunity protein and PedD is the precursor processing enzyme. Molecular Microbiology 17, 515-522.

Verellen, T.L.J., Bruggeman, G., Van Reenen, C.A., Dicks, L.M.T., Vandamme, E.J., 1998. Fermentation optimisation of plantaricin 423, a bacteriocin produced by Lactobacillus plantarum 423. Journal of Fermentation and Bioengineering 86, 174-179.

Vignolo, G.M., De Kairuz, M.N., De Ruiz Holgado, A.A.P., Oliver, G., 1995. Influence of growth conditions on the production of lactocin 705, a bacteriocin produced by Lactobacillus casei CRL 705. Journal of Applied Bacteriology 78, 5-10.

Yang, R., Ray, B., 1994. Factors influencing production of bacteriocins by lactic acid bacteria. Food Microbiology 11, 281-291.

Yang, R., Johnson, M., Ray, B., 1992. Novel method to extract large amounts of bacteriocins from lactic acid bacteria. Applied and Environmental Microbiology 58, 3355-3359.

Yousef, A.E., Luchansky, J.B., Degnan, A.J., Doyle, M.D., 1991. Behavior of Listeria monocytogenes in wiener exudates in the presence of Pediococcus acidilactici $\mathrm{H}$ or pediocin $\mathrm{AcH}$ during storage at 4 or $25^{\circ} \mathrm{C}$. Applied and Environmental Microbiology 57, 1461-1467. 